\title{
IMPACT OF FLOWER CULTIVATION ON FARMERS' LIVELIHOOD IN SOME SELECTED AREA OF BANGLADESH
}

\author{
M.W.A. SETU ${ }^{1}$, I.B. ISLAM ${ }^{1}$, M.S. ALI ${ }^{1}$, M.H.K. SUJAN *2, H.M.S. ISLAM ${ }^{1}$
}

\author{
Address: \\ ${ }^{1}$ Dept. of Agricultural Extension and Information System, Sher-e-Bangla Agricultural University, Dhaka 1207, \\ Bangladesh \\ ${ }^{2}$ Department of Development and Poverty Studies, Faculty of Agribusiness Management, Sher-e-Bangla Agricultural \\ University, Dhaka 1207, Bangladesh \\ * Corresponding author e-mail: mhksujan@gmail.com
}

\begin{abstract}
The study was designed to investigate the impact of flower cultivation on farmers' livelihood in Jhenaidah district of Bangladesh. For this purpose, primary data were collected from 115 flower cultivators and 45 controls from February to March, 2017. Descriptive statistics, step wise regression and Constraints Facing Index (CFI) were used for analysing data. Result shows that most of the farmers (76.5\%) gained medium livelihood improvement through flower cultivation, while 13.9 percent had high impact of flower cultivation on their livelihood. Among the entire variables - attitude towards flower cultivation alone contribute 39.5 percent of the variation of the impact. The Majority (73.9\%) of the flower farmers had medium constraints in flower cultivation. As per Constraint Faced Index (CFI) high labour wages positioned the first place as the constraints of flower cultivation. But the composite impact of flower cultivation on farmers' livelihood was moderate. Respective authorities like DAE, NGOs should implement and popularize flower cultivation project on a massive scale for improving farmers' livelihood.
\end{abstract}

Keywords: Bangladesh, Flower cultivation, Jhenaidah, Impact, Livelihood JEL: Q12, Q13, Q17, Q18

\section{INTRODUCTION}

Bangladesh is a densely populated and agro-based developing country. About $76 \%$ of her people lives in rural area, and $47.5 \%$ of the total manpower is involved in agriculture. Most of the rural people are dependent for their livelihood mainly on agricultural activities. Agriculture sector can be divided into many subsectors like livestock, poultry farming, forestry and horticulture etc. Floriculture is a branch of horticulture dealing with the cultivation of flowers etc. In Bangladesh, presently flower is related with almost all the festivals and its demand have been increased with the increasing income of citizen. Even fresh flower is essential in daily life for decoration. In Bangladesh, growth of commercial flower production can be traced back to early 70 s to mid-80s when large-scale commercial production started in Jikargacha upazila of Jessore district (Sultana, 2003). Within decades, flower cultivation has grown into an industry. Bangladesh had to spend roughly 2-3 million Bangladesh Taka (BDT) in importing flowers and ornamental plants to meet the market demand in every year since 2009 (Sayla, 2010). But the country has around $4,66,600$ hectares of fallow land which can be used to produce flowers to meet up the domestic demand and also for exporting (BBS, 2011). Now, flowers are grown on nearly 1,000 acres of land in 22 districts, mostly in Khulna and Dhaka divisions. At least 1.5 lakh people are involved in the production, distribution and sales. The total sale of flower was 31 million USD in 2009-10, which rose to around 100 million USD in 2014-15 fiscal year (BBS, 2016). The increase in area under floriculture and enthusiasm of the growers revealed the potentiality of this industry. Under floriculture industry, the employment generation for both men and women are increased at about 15.79 percent per year (Agrislide, 2017). This raising floriculture industry have a great impact on farmers' livelihood. Impact can be characterized as positive and negative, essential and optional long haul effects produced by a developmental intervention, directly or indirectly, planned or unintended (Garbarino and Holland, 2009). Because of favourable weather and soil fertility flower farmers get three to four times higher return than that of from any other crop and thus, flower has become a cash crop. Although flower cultivation has an enormous effect and potential on the farmers' livelihood improvement, little research has been conducted regarding the impact of flower cultivation on farmers' livelihood particularly in Bangladesh. Hence, on the basis of the above considerations and to formulate suitable strategic measures for the livelihood improvement of the flower cultivators, this research focuses on socio-economic characteristics of flower cultivators and examines the impact of flower cultivation on their livelihood patterns. 
The floriculture industry is increasing every year. It is now-a-days an industry of billions of USD and employs millions of people throughout the world. (Donohue, 2003). Around the world almost 120 countries are engaged in of floriculture and about $90 \%$ of the demanded flowers come from America, Asia and Europe. (Ghule and Menon, 2013). Martsynovska (2005) observed European Union (44\%) as the major flower producer, followed by China (12\%), USA (12\%), Japan (11\%), Canada (4\%), Colombia (3\%), Korea (2\%) and others $(10 \%)$ of the world production. Hemert (2005) studied that the floriculture industry of Netherlands is operating on world level. Haque et al. (2012) identified that per hectare costs of marigold cultivation was BDT 1,47,234 and net return were BDT $1,17,812$, respectively. The net return was $81 \%$ hi gher than lentil, $85 \%$ higher than mustard, and $6 \%$ lower than potato cultivation. Mou (2012) studied the profitability of flower cultivation under three district of Bangladesh and found a gross margin around BDT 13,59,824. Mou (2012) also found higher gross margin per hectare from flower cultivation (BDT 13,59,824) than that of vegetables (BDT 46,362) in Mymensingh district. Jahan (2009) examined the production and marketing cost structure and profitability of some selected flowers and found net marketing margin was highest for retailers and lowest for wholesaler. Seraj (2007) also stated that there is a huge potentiality of flower business in Bangladesh. Bangladesh exported Cut flowers into a few destinations like India, Pakistan, Italy, Portugal, Saudi Arabia, the United States, South Korea, the Philippines, Singapore, Japan, Germany, Britain, Denmark and France. Bagade et al. (2008) examined cut flower production, disposal and marketing in Ratnagiri district, Maharashtra, India and found a total marketed surplus of gerbera valued in Indian rupee (Rs.) 3,88,993 and Rs. 3,66,936 for cooperative and private unit, respectively. Gajanana $\boldsymbol{e t} \boldsymbol{a l}$. (2005) found The gross returns and benefit cost ratio about Rs. 4,88,668 and 2.69, respectively for a cut flower Carnation (Dianthus caryophyllus). Donohue (2003) stated that the floriculture industry has directly contributing to the economic development of the country through creating of employment opportunities and earning of foreign exchange.

\section{Concept of livelihood}

Livelihoods can be defined as "a means of gaining living", which refers to the way of living rather than income and consumption alone (Avnimelech, 1998; Chambers and Conway, 1991). A livelihood comprises people, their capabilities and activities for means of living, including assets (tangible and intangible). Tangible assets are resources and stores, and intangible assets are claim and access (Avnimelech, 1998). Afterwards, several researchers used this definition with minor modification (Scoones, 1998). The theory of livelihood encompasses not only the income generating activities pursued by a household and its individuals, but also entails the social institutions, intra-household relations, and mechanisms of access to resources through the life cycle (Ellis, 2000).

\section{MATERIAL AND METHODS}

The study was conducted in the Kaliganj upazila under Jhenaidah district of Bangladesh. Among twelve unions of Kaligonj Trilochanpur union was selected purposively as the study area.

All the farmers of Trilochanpur union who cultivate flower constituted the population of the study. The total number of the flower farmers was 128 . Thus, 128 flower cultivators constituted the population of the study which is shown in the following Table 1 . But 13 farmers were not available at the time of data collection. Hence, the sample of the study becomes 115 .

Table 1. Population of the study area

\begin{tabular}{lllcc}
\hline $\begin{array}{l}\text { Selected } \\
\text { Upazila }\end{array}$ & Selected area & $\begin{array}{l}\text { Selected } \\
\text { block }\end{array}$ & $\begin{array}{l}\text { Number of } \\
\text { respondents }\end{array}$ & $\begin{array}{l}\text { Sample } \\
\text { size }\end{array}$ \\
\hline $\begin{array}{l}\text { Kaliganj } \\
\text { (Jhenaidah }\end{array}$ & $\begin{array}{l}\text { Trilochanpur } \\
\text { union }\end{array}$ & $\begin{array}{l}\text { Kalukhali } \\
\text { Baliadanga }\end{array}$ & 51 & 45 \\
$\begin{array}{l}\text { District) } \\
\text { Sample }\end{array}$ & & & 128 & 70 \\
\hline
\end{tabular}

Forty (40) farmers from the same study area were selected as the control group who did not cultivate flowers. To ensure similar socio-economic conditions for both the control and test groups, a two-way stratified random sampling technique was used (Mazumder and Wencong, 2015), in which education and farm size were considered as two individual strata.

\section{Data collection methods}

Individual interviews were used in the survey and were conducted in a face-to- face (Bryman, 2001) situation by the researcher. A structured interview schedule was prepared containing open and closed formed questions. The schedule was pre-tested with 15 randomly selected flower farmers in the study area. The pre-test was helpful in identifying faulty questions and statements in the draft schedule. Data were collected by the researcher personally. The primary data were collected from February to March, 2017. Two years back (January, 2015) data were considered through respondents' memory recall.

\section{Variables and their measurement techniques}

Twelve independent variables were selected which included age (year), level of education (years of schooling), family size (no. of members), farm size (hectare), annual family income ('1000 BDT), annual income from flower cultivation ('1000 BDT), duration of floral cultivation (years of flower cultivation), extension media contact (no. of exposure to eight alternative media), training exposure (no. of days), availability of marketing information (no. of exposure to six alternative sources of information), attitude towards flower cultivation (any score from +2 to -2 based on farmers' thinking) and knowledge on flower cultivation (no. of correct answer out of 10 questions regarding flower cultivation).

The dependent variable of this study was the "impact of flower cultivation on farmers' livelihood in Jhenaidah District of Bangladesh". It was measured in five dimensions which included: 
a) CSFA Changes Score in Food Availability (three alternative responses like adequate, inadequate and shortage basis to each of the five food items and score of three, two and one were assigned for those alternative responses, respectively then summing up),

b) CSCV Changes Score in Clothes Value (1 score for 1000 BDT),

c) CSHC Changes Score in Housing Condition (assigned 1 score for each characteristics of houses like roof, walls and floor then summing up),

d) CSAGHT Changes Score in Ability to Get Health Treatment (2, 1 and 0 scores were assigned for frequent, seldom and not at all availability for each one of five health treatment providers then summing up) and

e) CSPSA Changes Score in Participation in Social Activities (2, 1 and 0 score were assigned for regularly, occasionally and no participation for each one of five selected social events then summing up).

Then, the final indicator, Flower Cultivation Impact (FCI) was constructed by using the Equation (1).

$F C I=C S F A+\mathrm{CSCV}+\mathrm{CSHC}+\mathrm{CSAGHT}+\mathrm{CSPSA}$

Constraints faced by farmers during flower cultivation From a number of mentionable cons traints faced by flower cultivators only ten were enlisted and ranked. These ten were high labour wages, lack of knowledge about flower preservation, lack of knowledge about modem technologies of flower cultivation, unavailability of labour, flower processing problem, poor marketing facilities, lack of improved propagating materials, lack of suitable sales center, lack of transportation and insufficient credit support. Constraints faced by farmers during flower cultivation were measured on the basis of extent of constraints in flower cultivation. The following scores were assigned against each of the problems:

\begin{tabular}{llllll}
\hline \multicolumn{4}{l}{ Extent of problem } & & \\
& $\begin{array}{l}\text { Very } \\
\text { High } \\
\text { problem }\end{array}$ & $\begin{array}{l}\text { High } \\
\text { problem }\end{array}$ & $\begin{array}{l}\text { Moderate } \\
\text { problem }\end{array}$ & $\begin{array}{l}\text { Little } \\
\text { problem }\end{array}$ & $\begin{array}{l}\text { No } \\
\text { problem }\end{array}$ \\
\hline Score & 4 & 3 & 2 & 1 & 0 \\
\hline
\end{tabular}

Flower cultivation constraints of a farmer were measured by asking him/her 10 questions related to different components of flower cultivation constraints. Thus, constraints in flower cultivation score of a respondent could range from 0 to 40 where 0 indicated "no constraints" and 40 indicated "very high constraints".

\section{Rank order of constraints in flower cultivation}

To ascertain the worst problem confrontation strategies Constraint Faced Index (CFI) was computed. There were ten problem faced strategies for coping with 10 selected items by the farmers in flower cultivation. They are presented below in rank order. A Constraint Faced Index (CFI) was computed for each constraints strategy (Eq. 2).

$C F I=f_{v h} \times 4+f_{h} \times 3+f_{m} \times 2+f_{l} \times 1+f_{n} \times 0$

Where:

CFI Constraint Faced Index

$f_{v h}$ No. of respondents faced very high constraint

$f_{h} \quad$ No. of respondents faced high cons traint

$f_{m}$ No. of respondents faced medium constraint

$f_{l} \quad$ No. of respondents faced low constraint

$f_{n} \quad$ No. of respondents faced no constraint

Constraint Faced Index (CFI) for each constraint strategies could range from 0 to 460 , where 0 indicating lowest extent of constraint and 460 indicating highest extent of cons traint.

Bogdan and Biklen (2006) insist that data analysis is an on-going part of data collection. Qualitative data were converted into quantitative numbers, if required, after processing, scaling and indexing of the necessary and relevant variables to perform subsequent statistical analysis for drawing inferences. SPSS/windows version 22.0, which offered statistical tools applied to social sciences were used for analysing the collected data. Both descriptive and analytical methods were employed in order to analyse the data. Descriptive techniques have been used to illustrate current situations, describe different variables separately and construct tables presented in results. These included: frequency distribution, percentage, range, mean and standard deviation. Statistical test like regression was used in this study.

To find out the contribution of selected characteristics of the farmers to their livelihood, the method of stepwise mul tiple regression was administrated and 12 independent variables were fitted together in step-wise multiple regression analysis.

The model used for this analysis can be explained as Eq. (3):

$Y=a+b_{1} X_{1}+b_{2} X_{2}+b_{3} X_{3}+b_{4} X_{4}+b_{5} X_{5}+b_{6} X_{6}+$ $b_{7} X_{7}+b_{8} X_{8}+b_{9} X_{9}+b_{10} X_{10}+b_{11} X_{11}+b_{12} X_{12}+e$

Where:

$\mathrm{Y}$ the impact of flower cultivation on farmers' livelihood;

$X_{I}$ the flower farmer's age,

$X_{2}$ level of education,

$\mathrm{X}_{3}$ family size,

$\mathrm{X}_{4}$ farm size,

$\mathrm{X}_{5}$ annual family income,

$\mathrm{X}_{6}$ annual income from flower cultivation,

$\mathrm{X}_{7}$ duration of floral cultivation,

$\mathrm{X}_{8}$ extension media contact,

$\mathrm{X}_{9}$ training exposure,

$\mathrm{X}_{10}$ availability of marketing information, 
$\mathrm{X}_{11}$ attitude towards flower cultivation and

$\mathrm{X}_{12}$ knowledge on flower cultivation.

On the other hand, $b_{1, \ldots \ldots, b_{12}}$ are regression coefficients of the corresponding independent variables, and $\mathrm{e}$ is random error, which is normally and independently distributed with zero mean and constant variance.

\section{RESULTS AND DISCUSSION}

\section{Characteristics of the farmers}

There were various characteristics of the farmers that might have consequence to livelihood. But in this study, twelve characteristics of them were selected as independent variables that might have great influence to the impact of flower cultivation on their livelihood.

\section{Age}

The age of the farmers has been varied from 25 to 62 years with a mean value of 45.41. Considering the recorded age farmers were classified into three categories namely young, middle and old aged following (MoYS, 2012). The distribution of the farmers in accordance of their age is presented in Table 2. Middle-aged farmers comprised the highest proportion (48.7 percent) followed by old aged category (35.7 percent) and the lowest proportion were made by the young ( 15.7 percent). The middle and old aged farmers were generally more involved in flower farming activities after the realization of current situation where the flower farming retuned more profit.

Table 2. Distribution of the farmers according to their age

\begin{tabular}{lllllll}
\hline Category & $\begin{array}{l}\text { Basis of } \\
\text { categorization } \\
\text { (years) }\end{array}$ & $\begin{array}{l}\text { Observed } \\
\text { range } \\
\text { (years) }\end{array}$ & $\begin{array}{l}\text { Farmers } \\
\text { Number }\end{array}$ & $\%$ & Mean & SD \\
\hline $\begin{array}{l}\text { Young } \\
\text { aged }\end{array}$ & $\leq 35$ & & 18 & 15.7 & \\
$\begin{array}{l}\text { Middle } \\
\text { aged }\end{array}$ & $36-50$ & & 56 & 48.7 & \\
$\begin{array}{l}\text { Old } \\
\text { aged }\end{array}$ & $>50$ & & 41 & 35.7 & \\
Sample & & $25-62$ & 115 & 100 & 45.4 & 9.10 \\
\hline
\end{tabular}

\section{Level of education}

The level of educational scores of the farmers ranged from 0 to 12 . Based on the educational scores, the farmers were classified into five categories. The distributions of farmers according to their level of education are presented in Table 3. Farmers under secondary education category constitute the highest proportion (47.0 percent) followed by primary education (31.3 percent). On the other hand, lowest $3.5 \%$ lies in above secondary education category. Can sign only (13.9 percent) and 4.3 percent respondents were under can't read and sign category. Therefore, the data reveals that $81.8 \%$ of the flower farmers' literate which is better than the average literacy rate of Bangladesh.

\section{Family size}

Family size of the farmers ranged from 3 to 7 . According to family size the farmers were classified into three categories namely small, medium and large family. The distribution of the cultivators according to their family size is presented in Table 4. Medium size family constitute the highest proportion (67.0 percent) followed by the small family (22.6 percent). Only 10.4 percent farmers had large family size. The findings indicated that average family size of the study area was smaller than the national average which was 4.85 (BBS, 2014). The trend of nuclear family has been rising in the study area and subsequently the family member becoming smaller than the extended family.

Table 3. Distribution of the farmers according to their level of education

\begin{tabular}{|c|c|c|c|c|c|c|}
\hline Category & $\begin{array}{l}\text { Basis of } \\
\text { categorization } \\
\text { (score) }\end{array}$ & $\begin{array}{l}\text { Observed } \\
\text { range } \\
\text { (score) }\end{array}$ & $\begin{array}{l}\text { Farmers } \\
\text { Number }\end{array}$ & $\%$ & Mean & SD \\
\hline $\begin{array}{l}\text { Can't read } \\
\text { and sign }\end{array}$ & 0 & & 5 & 4.3 & & \\
\hline $\begin{array}{l}\text { Can sign } \\
\text { only }\end{array}$ & 0.5 & & 16 & 13.9 & & \\
\hline $\begin{array}{l}\text { Primary } \\
\text { education }\end{array}$ & $1-5$ & & 36 & 31.3 & & \\
\hline $\begin{array}{l}\text { Secondary } \\
\text { education }\end{array}$ & $6-10$ & & 54 & 47.0 & & \\
\hline $\begin{array}{l}\text { Above } \\
\text { secondary }\end{array}$ & $>10$ & & 4 & 3.5 & & \\
\hline Sample & & $0-12$ & 115 & 100 & 4.79 & 3.40 \\
\hline
\end{tabular}

Table 4. Distribution of the farmers according to their family size

\begin{tabular}{lllllll}
\hline Category & $\begin{array}{l}\text { Basis of } \\
\text { Categorization } \\
\text { (score) }\end{array}$ & $\begin{array}{l}\text { Observed } \\
\text { range } \\
\text { (score) }\end{array}$ & $\begin{array}{l}\text { Farmers } \\
\text { Number }\end{array}$ & Mean & SD \\
\hline $\begin{array}{l}\text { Small } \\
\text { family }\end{array}$ & $\begin{array}{l}\leq 3 \\
\text { (Mean-1SD) }\end{array}$ & & 26 & 22.6 & \\
$\begin{array}{l}\text { Medium } \\
\text { family }\end{array}$ & $\begin{array}{l}4-6 \\
\text { (Mean } \pm \text { SD) }\end{array}$ & & 77 & 67.0 & & \\
$\begin{array}{l}\text { Large } \\
\text { family }\end{array}$ & $>6$ & 12 & 10.4 & & \\
Sample & (Mean+1SD) & $3-7$ & 115 & 100 & 4.62 & 1.27 \\
\hline
\end{tabular}

\section{Farm size}

The farm size of the farmers ranged from 0.15 ha to 4.71 ha with a mean and standard deviation of 1.42 and 1.03, respectively. Based on their farm size, the farmers were classified into five categories following the categorization according to DAE (1999). The distribution of the farmers according to their farm size is presented in Table 5. Medium farm holder constituted the highest proportion (53.9 percent) followed by small farm holder (33.9 percent). The average farm size of the farmers of the study area (1.42 ha) was higher than that of national average (0.60 ha) of Bangladesh (BBS, 2014). The cultivator with marginal farm size has very little scope to experiment about new technologies as their earnings depend on mainly in agriculture.

\section{Annual family income}

On the basis of annual income, the flower cultivators were classified into three categories namely low, medium and high annual family income. The distribution of the flower cultivators according to their annual income is presented in Table 6. Data reveals that the flower cultivators having medium annual income constitute the highest proportion (71.3 percent), while the lowest proportion in low income (12.2 percent) followed by high income (16.5 percent). Overwhelming majority (87.80 percent) of flower 
cultivators have low to medium level annual family income.

Table 5. Distribution of the farmers according to their effective farm size

\begin{tabular}{lllllll}
\hline Category & $\begin{array}{l}\text { Basis of } \\
\text { categorization } \\
\text { (ha) }\end{array}$ & $\begin{array}{l}\text { Observed } \\
\text { range } \\
\text { (ha) }\end{array}$ & $\begin{array}{l}\text { Farmers } \\
\text { Number }\end{array}$ & Mean & SD \\
\hline Landless & $\leq 0.02$ & & 0 & 0 & & \\
Marginal & $0.021-0.20$ & & 3 & 2.6 & & \\
Small & $0.21-1.00$ & & 39 & 33.9 & & \\
Medium & $1.01-3.0$ & & 62 & 53.9 & & \\
Large & $>3$ & & 11 & 9.6 & & \\
Sample & & $0.15-4.71$ & 115 & 100 & 1.42 & 1.03 \\
\hline
\end{tabular}

Table 6. Distribution of the farmers according to their annual family income

\begin{tabular}{lllllll}
\hline Category & $\begin{array}{l}\text { Basis of } \\
\text { categorization } \\
\text { ('000' Tk.) }\end{array}$ & $\begin{array}{l}\text { Observed } \\
\text { range } \\
\text { ('000’Tk.) }\end{array}$ & $\begin{array}{l}\text { Farmers } \\
\text { Number }\end{array}$ & Mean & SD \\
\hline $\begin{array}{l}\text { Low } \\
\text { income }\end{array}$ & $\begin{array}{l}\leq 72 \\
\text { (Mean-1SD) }\end{array}$ & 14 & 12.2 & \\
$\begin{array}{l}\text { Medium } \\
\text { income }\end{array}$ & $\begin{array}{l}73-325 \\
\text { (Mean } \pm \mathrm{SD})\end{array}$ & 82 & 71.3 & \\
$\begin{array}{l}\text { High } \\
\text { income }\end{array}$ & $\begin{array}{l}\text { (Mean+1SD) } \\
\text { Sample }\end{array}$ & & 19 & 16.5 & & \\
(Mean & $58-540$ & 115 & 100 & 198.44 & 126.33 \\
\hline
\end{tabular}

\section{Annual income from flower cultivation}

On the basis of annual income from flower cultivation, the flower cultivators were classified into three categories namely low, medium and high annual income from flower cultivation. The distribution of the flower cultivators according to their income from flower cultivation is presented in Table 7. Data reveals that the flower cultivators having medium income from flower cultivation constitute the highest proportion (78.3 percent), followed by high income (21.7 percent).

Table 7. Distribution of the farmers according to their annual income from flower cultivation

\begin{tabular}{lllllll}
\hline Category & $\begin{array}{l}\text { Basis of } \\
\text { categorization } \\
\text { ('000'Tk.) }\end{array}$ & $\begin{array}{l}\text { Observed } \\
\text { range } \\
\text { ('000'Tk.) }\end{array}$ & $\begin{array}{l}\text { Farmers } \\
\text { Number }\end{array}$ & Mean & SD \\
\hline $\begin{array}{l}\text { Low } \\
\text { income }\end{array}$ & $\begin{array}{l}\leq 26 \\
\text { (Mean-1SD) }\end{array}$ & 0 & 0 & & \\
$\begin{array}{l}\text { Medium } \\
\text { income }\end{array}$ & $\begin{array}{l}27-124 \\
\text { (Mean } \pm \text { SD) }\end{array}$ & 90 & 78.3 & & \\
$\begin{array}{l}\text { High } \\
\text { income }\end{array}$ & $\begin{array}{l}\text { (Mean+1SD) } \\
\text { Sample }\end{array}$ & & 25 & 21.7 & & \\
\hline
\end{tabular}

\section{Duration of flower cultivation}

On the basis of duration, the flower cultivators were classified into three categories namely low, medium and high experience. The distribution of the flower cultivators according to their duration of flower cultivation is given in Table 8. Majority (67.0 percent) of the cultivator fell in medium duration of flower cultivation category, whereas only 16.5 percent in low duration of flower cultivation category and 16.5 percent in high duration of flower cultivation category.
Table 8. Distribution of the farmers according to their duration of flower cultivation

\begin{tabular}{lllllll}
\hline Category & $\begin{array}{l}\text { Basis of } \\
\text { categorization } \\
\text { (year) }\end{array}$ & $\begin{array}{l}\text { Observed } \\
\text { range } \\
\text { (year) }\end{array}$ & $\begin{array}{l}\text { Farmers } \\
\text { Number }\end{array}$ & Mean & SD \\
\hline $\begin{array}{l}\text { Low } \\
\text { duration }\end{array}$ & $\begin{array}{l}\leq 7 \\
\text { (Mean-1SD) }\end{array}$ & 19 & 16.5 & \\
$\begin{array}{l}\text { Medium } \\
\text { duration }\end{array}$ & $\begin{array}{l}\text { 8-12 } \\
\text { (Mean } \pm \text { SD) }\end{array}$ & 77 & 67.0 & & \\
$\begin{array}{l}\text { High } \\
\text { duration }\end{array}$ & $>12($ Mean+1SD) & 19 & 16.5 & & \\
\begin{tabular}{l} 
Sample \\
\hline
\end{tabular} & $5-15$ & 115 & 100 & 10.0 & 2.57 \\
\hline
\end{tabular}

\section{Extension media contact}

The farmers were classified into three categories on the basis of their exposure to farming information namely low, medium and high extension media contact of the farmers. Data shows that the highest proportion $(73.9 \%)$ of the farmers had medium extension contact as compared to 15.7 percent of them having low extension contact (Table 9). Low extension contact might be the reason that some respondent may think that they have enough knowledge about farming activities. They receive information from their neighbours, relatives and workmates etc.

Table 9. Distribution of the farmers according to their extension media contact

\begin{tabular}{lllllll}
\hline Category & $\begin{array}{l}\text { Basis of } \\
\text { categorization } \\
\text { (score) }\end{array}$ & $\begin{array}{l}\text { Observed } \\
\text { range } \\
\text { (score) }\end{array}$ & $\begin{array}{l}\text { Farmers } \\
\text { Number }\end{array}$ & Mean & SD \\
\hline $\begin{array}{l}\text { Low } \\
\text { contact }\end{array}$ & $\begin{array}{l}\leq 21 \\
\text { Mean - 1SD) }\end{array}$ & 18 & 15.7 & & \\
$\begin{array}{l}\text { Medium } \\
\text { contact }\end{array}$ & $\begin{array}{l}22-26 \\
\text { (Mean } \pm \text { SD) }\end{array}$ & & 85 & 73.9 & & \\
$\begin{array}{l}\text { High } \\
\text { contact }\end{array}$ & $>26$ & 12 & 10.4 & & \\
Sample & (Mean+1SD) & & 115 & 100 & 23.85 & 2.03 \\
\hline
\end{tabular}

\section{Training exposure}

Based on the training exposure score, the flower cultivators were classified into four categories namely no training, low, medium and high training exposure. The distribution of the flower cultivators according to their training exposure is presented in Table 10. Highest proportion (80.9 percent) of the flower cultivators had medium training exposure compared to 13.0 percent in high training exposure. Trained flower cultivators can face any kind of challenges about the adverse situation in their cultivation. So, they show favourable attitude toward adoption of modern flower cultivation technologies.

Table 10. Distribution of the flower cultivators according to their training exposure

\begin{tabular}{|c|c|c|c|c|c|c|}
\hline Category & $\begin{array}{l}\text { Basis of } \\
\text { categorization } \\
\text { (score) }\end{array}$ & $\begin{array}{l}\text { Observed } \\
\text { range } \\
\text { (score) } \\
\end{array}$ & $\begin{array}{l}\text { Farmers } \\
\text { Number }\end{array}$ & $\%$ & Mean & SD \\
\hline \multicolumn{2}{|c|}{ Not raining 0} & & 6 & 5.2 & & \\
\hline $\begin{array}{l}\text { Low } \\
\text { exposure }\end{array}$ & $\begin{array}{l}\leq 2 \\
\text { (Mean-1SD) }\end{array}$ & & 1 & 0.9 & & \\
\hline $\begin{array}{l}\text { Medium } \\
\text { exposure }\end{array}$ & $\begin{array}{l}3-9 \\
(\text { Mean } \pm \text { SD) }\end{array}$ & & 93 & 80.9 & & \\
\hline $\begin{array}{l}\text { High } \\
\text { exposure }\end{array}$ & $\begin{array}{l}>9 \\
(\text { Mean+1SD) }\end{array}$ & & 15 & 13.0 & & \\
\hline Sample & & $0-15$ & 115 & 100 & 5.93 & 3.03 \\
\hline
\end{tabular}




\section{Availability of marketing information}

Based on availability of marketing information score, the flower farmers were classified into three categories namely less, medium and high availability of marketing information. The distribution of the flower farmers as per their availability of marketing information is presented in Table 11. Data reveals that the highest proportion (64.3 percent) of the flower farmers had medium availability of marketing information, while 22.6 percent had high availability of marketing information and the lowest 13.0 percent had low availability of marketing information category.

Table 11. Distribution of the flower farmers according to availability of marketing information

\begin{tabular}{lllllll}
\hline Category & $\begin{array}{l}\text { Basis of } \\
\text { categorization } \\
\text { (score) }\end{array}$ & $\begin{array}{l}\text { Observed } \\
\text { range } \\
\text { (score) }\end{array}$ & $\begin{array}{l}\text { Rural women } \\
\text { Number }\end{array}$ & Mean & SD \\
\hline $\begin{array}{l}\text { Less } \\
\text { information }\end{array}$ & $\begin{array}{l}\leq 16 \\
\text { (Mean-1SD) }\end{array}$ & & 15 & 13.0 & \\
$\begin{array}{l}\text { Medium } \\
\text { information }\end{array}$ & $\begin{array}{l}\text { 17-20 } \\
\text { (Mean } \pm \text { SD) }\end{array}$ & & 74 & 64.3 & & \\
$\begin{array}{l}\text { High } \\
\text { information }\end{array}$ & $>20$ & 26 & 22.6 & & \\
Sample & (Mean+1SD) & $13-21$ & 115 & 100 & 18.65 & 1.81 \\
\hline
\end{tabular}

\section{Attitude towards flower cultivation}

On the basis of attitude towards flower cultivation, the respondents were categorized into three classes, namely poorly favourable attitude, moderately favourable attitude and highly favourable attitude (Table 12). Data shows that most of the farmers (61.7 percent) had a moderately favourable attitude towards flower cultivation while 25.2 and 13.0 percent of them had highly and poorly favourable attitude, respectively. The attitude of the respondents expressed their perception about flower cultivation. It helped the researcher to judge or measure the acceptance/rejection of flower cultivation in the rural area.

Table 12. Distribution of the farmers according to their attitude towards flower cultivation

\begin{tabular}{|c|c|c|c|c|}
\hline Category & $\begin{array}{l}\text { Basis of } \\
\text { categorization } \\
\text { (score) }\end{array}$ & $\begin{array}{l}\text { Observed } \\
\text { range } \\
\text { (score) }\end{array}$ & $\begin{array}{l}\text { Farmers } \\
\text { Number }\end{array}$ & $\%$ \\
\hline $\begin{array}{l}\text { Poorly } \\
\text { favourable } \\
\text { attitude }\end{array}$ & $\begin{array}{l}\leq 3 \\
(\text { Mean -1SD) }\end{array}$ & & 15 & 13.0 \\
\hline $\begin{array}{l}\text { Moderately } \\
\text { favourable } \\
\text { attitude }\end{array}$ & $\begin{array}{l}4-9 \\
(\text { Mean } \pm \text { SD) }\end{array}$ & & 71 & 61.7 \\
\hline $\begin{array}{l}\text { Highly } \\
\text { favourable } \\
\text { attitude }\end{array}$ & $\begin{array}{l}>9 \\
(\text { Mean+1SD) }\end{array}$ & & 29 & 25.2 \\
\hline Sample & & $2-12$ & 115 & 1006.112 .71 \\
\hline
\end{tabular}

\section{Knowledge on flower production}

Based on the flower production knowledge scores, the farmers were classified into three categories namely poor knowledge, moderate knowledge and sound knowledge (Table 13). An overwhelming majority $(61.7 \%)$ of the farmers had moderate flower production knowledge while 25.3 percent had sound knowledge on flower cultivation.
Table 13. Distribution of the farmers according to their knowledge on flower production

\begin{tabular}{|c|c|c|c|c|c|}
\hline Category & $\begin{array}{l}\text { Basis of } \\
\text { categ orization } \\
\text { (score) }\end{array}$ & $\begin{array}{l}\text { Observed } \\
\text { range } \\
\text { (score) }\end{array}$ & $\begin{array}{l}\text { Farmers } \\
\text { Number }\end{array}$ & $\%$ & Mean SD \\
\hline $\begin{array}{l}\text { Poor } \\
\text { knowledge }\end{array}$ & $\begin{array}{l}\leq 20 \\
\text { (Mean-1SD) }\end{array}$ & & 15 & 13.0 & \\
\hline $\begin{array}{l}\text { Moderate } \\
\text { knowledge }\end{array}$ & $\begin{array}{l}21-24 \\
(\text { Mean } \pm \text { SD) }\end{array}$ & & 71 & 61.7 & \\
\hline $\begin{array}{l}\text { Sound } \\
\text { knowledge }\end{array}$ & $\begin{array}{l}>24 \\
(\text { Mean+1SD) }\end{array}$ & & 29 & 25.3 & \\
\hline Sample & & $19-26$ & 115 & 100 & $22.67 \quad 1.95$ \\
\hline
\end{tabular}

\section{Impact of flower cultivation on farmers' livelihood}

In this study, impact of flower cultivation on farmers' livelihood was measured in five dimensions: a) change in food availability, b) changes in clothes value, c) changes in housing condition, d) changes in ability to get health treatment and e) changes in participation in social activities. The difference between 2015 and 2017 was measured both for study and control group respondents. Finally, the study group was compared with the control group as compared by Mazumder and Lu (2015). The changed results for the study are presented in bellow:

\section{A compared livelihood condition index for Study Group} (SG) and Control Group (CG)

A comparison between Study Group (SG) and Control Group (CG) was done to find out the flower cultivation impact on farmers' livelihood. The distributions of changed livelihood with respect to study group and control group respondents are shown in Table14. Flower cultivators had mentionable improvement in their livelihood. Study group mean score of livelihood was 7.37 while the control group gained only 5.25. The changed score of flower cultivation impact:

Livelihood Impact $=$ Mean score of study group livelihood - Mean score of control group livelihood $=7.37-5.25=$ 2.12

The score of livelihood impact was found 2.12. So, there was a positive impact of flower cultivation. The study also found significant impact of study group that is the flower cultivation on farmers' livelihood at $1 \%$ significance level from t-test.

Table 14. Study group and control group respondents' livelihood based on their changed value

\begin{tabular}{|c|c|c|c|c|}
\hline \multicolumn{2}{|c|}{$\begin{array}{l}\text { Sl. Livelihood indicators } \\
\text { No. }\end{array}$} & $\begin{array}{l}\text { Study Group } \\
\text { (changed } \\
\text { mean value } \\
\text { differences) }\end{array}$ & $\begin{array}{l}\text { Control Group } \\
\text { (changed mean } \\
\text { value } \\
\text { differences) }\end{array}$ & t-test \\
\hline 1 & Food availability & 2.40 & 1.82 & $3.43^{* * * *}$ \\
\hline 2 & Clothes value & 0.92 & 0.47 & $3.09^{* * *}$ \\
\hline 3 & Housing condition & 0.97 & 0.72 & $2.96^{* * *}$ \\
\hline 4 & $\begin{array}{l}\text { Ability to get health } \\
\text { treatment }\end{array}$ & 1.12 & 0.75 & $1.71^{* * * *}$ \\
\hline 5 & $\begin{array}{l}\text { Participation in social } \\
\text { activities }\end{array}$ & 1.97 & 1.47 & $1.89^{* * * *}$ \\
\hline \multicolumn{2}{|c|}{ Sample } & 7.37 & 5.25 & $2.74^{* * * *}$ \\
\hline
\end{tabular}

Impact on farmers' livelihood through flower cultivation On the basis of impact on farmers' livelihood through flower cultivation, the respondents were categorized into three categories namely low, medium and high impact (positive) as shown in Table 15. Highest 76.5 percent of 
the farmers had medium impact while 13.9 percent had high impact of livelihood through flower cultivation. Thus, an overwhelming majority $(90.4 \%)$ of the farmers had medium to high impact of flower cultivation on their livelihood.

Table 15. Impact of flower cultivation on farmers' livelihood

\begin{tabular}{lllllll}
\hline Category & $\begin{array}{l}\text { Basis of } \\
\text { categorization } \\
\text { (score) }\end{array}$ & $\begin{array}{l}\text { Observed } \\
\text { range } \\
\text { (score) }\end{array}$ & $\begin{array}{l}\text { Farmers } \\
\text { Farmers }\end{array}$ & $\%$ & Mean SD \\
\hline $\begin{array}{l}\text { Low } \\
\text { impact }\end{array}$ & $\begin{array}{l}\leq 3 \\
\text { (Mean-1SD) }\end{array}$ & 11 & 9.6 & \\
$\begin{array}{l}\text { Medium } \\
\text { impact }\end{array}$ & $\begin{array}{l}\text { (Mean } \pm \text { SD) } \\
\text { High }\end{array}$ & & 88 & 76.5 & & \\
$\begin{array}{l}>10 \\
\text { impact }\end{array}$ & (Mean+1SD) & & 16 & 13.9 & & \\
Sample & & $3-16$ & 115 & 100 & 6.86 & 3.20 \\
\hline
\end{tabular}

\section{Contribution of selected characteristics on the respondents' livelihood}

Table 16 shows the summarized results of step-wise multiple regression analysis with 12 independent variables on farmers' livelihood through flower cultivation. It was observed that out of 12 variables only 5 independent variables namely attitude towards flower cultivation $\left(X_{11}\right)$, annual income from flower cultivation $\left(X_{6}\right)$, level of education $\left(\mathrm{X}_{2}\right)$, annual family income $\left(X_{5}\right)$ and knowledge on flower cultivation $\left(X_{12}\right)$ were formed significant influence into the regression equation. The other seven variables were not entered into regression equation. So, the obtained regression equation was:

$\begin{array}{llll}Y=5.027+0.455 & X_{11}+0.021 X_{6}+0.206 X_{2}+ \\ 0.010 X_{5}+0.440 X_{12}+e & & \\ \text { Multiple R } & 0.721 & \text { R-square } & 0.519 \\ \text { Adjusted R-square } & 0.497 & \text { F-ratio } & 6.060 \\ \text { Standard error of } & 2.27 & \text { Constant } & 5.027\end{array}$

estimate

The multiple $\mathrm{R}$ and $\mathrm{R}^{2}$ values were found 0.721 and 0.519 , respectively and the corresponding F-ratio was 6.060 which were significant at $1 \%$ level. For determining unique contribution of each of the five variables the increase in $\mathrm{R}^{2}$ value was determined on livelihood. These five variables jointly explained $49.7 \%$ of the total variation. Attitude towards flower cultivation alone contribute highest $39.5 \%$ of the variation whereas annual income from flower cultivation, level of education, annual family income and knowledge on flower cultivation contributed $2.3 \%, 2.8 \%, 2.8 \%$ and $2.3 \%$ variation to the impact of flower cultivation on farmers' livelihood, respectively.

\section{Constraints faced by the farmers in flower cultivation}

Based on the constraints in flower cultivation scores, the respondents were classified into three categories namely low, medium and high constraints in flower cultivation (Table 17). An overwhelming majority $(73.9 \%)$ of the respondents had medium constraints in flower cultivation while 14.8 percent had low constraints.

Table 17. Distribution of the respondent according to their constraints in flower cultivation

\begin{tabular}{|c|c|c|c|c|c|}
\hline \multirow[t]{2}{*}{ Category } & \multirow{2}{*}{$\begin{array}{l}\text { Basis of } \\
\text { categorization } \\
\text { (score) }\end{array}$} & \multirow{2}{*}{$\begin{array}{l}\text { Observed } \\
\text { range } \\
(\text { score })\end{array}$} & \multicolumn{2}{|c|}{ Respondents } & \multirow[t]{2}{*}{ Mean SD } \\
\hline & & & Number & $\%$ & \\
\hline $\begin{array}{l}\text { Low } \\
\text { constraints }\end{array}$ & $\begin{array}{l}\leq 24 \\
\text { (Mean -1SD) }\end{array}$ & & 17 & 14.8 & \\
\hline $\begin{array}{l}\text { Medium } \\
\text { constraints }\end{array}$ & $\begin{array}{l}25-28 \\
(\text { Mean } \pm \text { SD) }\end{array}$ & & 85 & 73.9 & \\
\hline $\begin{array}{l}\text { High } \\
\text { constraints }\end{array}$ & $\begin{array}{l}>28 \\
(\text { Mean+1SD) }\end{array}$ & & 13 & 11.3 & \\
\hline Sample & & $22-31$ & 115 & 100 & 26.261 .77 \\
\hline
\end{tabular}

\section{Rank order of constraints in flower cultivation}

As per Constraints Faced Index (CFI), high labour wages ranked the first and insufficient credit support positioned the last place (Table 18). The highest constraint faced by the farmers in flower cultivation was high labour wages. This might be caused because of the people more or less invest their labour at their own business or farming activities. The lowest constraint in flower cultivation at the study area was insufficient credit support. This might be happened because of many NGOs were working to provide credit at the study area.

Table 16. Summary of step wise multiple regression analysis showing the contribution of selected characteristics of the respondents to the impact of their livelihood through flower cultivation

\begin{tabular}{|c|c|c|c|c|c|}
\hline Variable & $\begin{array}{l}\text { Standardized Partial } \\
\beta \text {-Coefficients }\end{array}$ & $\begin{array}{l}\text { t-value } \\
\text { (probability level) }\end{array}$ & $\begin{array}{l}\text { Adjusted } \\
\mathrm{R}^{2}\end{array}$ & $\begin{array}{l}\text { Increase } \\
\text { in } \mathrm{R}^{2}\end{array}$ & $\begin{array}{l}\text { Variation } \\
\text { explained } \\
(\%)\end{array}$ \\
\hline $\begin{array}{l}\text { Attitude towards } \\
\text { flower cultivation }\left(\mathrm{X}_{11}\right)\end{array}$ & 0.455 & $2.84(0.005)$ & 0.395 & 0.395 & 39.5 \\
\hline $\begin{array}{l}\text { Annual income } \\
\text { from flower cultivation }\left(\mathrm{X}_{6}\right)\end{array}$ & 0.021 & $3.65(0.000)$ & 0.418 & 0.023 & 2.3 \\
\hline Level of education $\left(\mathrm{X}_{2}\right)$ & 0.206 & $3.18(0.002)$ & 0.446 & 0.028 & 2.8 \\
\hline Annual family income $\left(\mathrm{X}_{5}\right)$ & 0.010 & $3.04(0.003)$ & 0.474 & 0.028 & 2.8 \\
\hline $\begin{array}{l}\text { Knowledge on } \\
\text { flower cultivation }\left(\mathrm{X}_{12}\right)\end{array}$ & 0.440 & $2.46(0.015)$ & 0.497 & 0.023 & 2.3 \\
\hline Total & & & & 0.497 & 49.7 \\
\hline
\end{tabular}


Table 18. Rank order of constraints faced by respondents in flower cultivation

\begin{tabular}{llrc}
\hline $\begin{array}{l}\text { S1. } \\
\text { No. }\end{array}$ & Nature of problems & $\begin{array}{c}\text { CFI } \\
\text { score }\end{array}$ & Rank \\
\hline 1. & High labour wages & 352 & $1^{\text {st }}$ \\
2. & Lack of knowledge about flower preservation & 343 & $2^{\text {nd }}$ \\
3. & Lack of knowledge about modem technologies of & 323 & $3^{\text {rd }}$ \\
& flower cultivation & 316 & $4^{\text {th }}$ \\
4. & Unavailability of labour & 304 & $5^{\text {th }}$ \\
5. & Flower processing problem & 293 & $6^{\text {th }}$ \\
6. & Poor marketing facilities & 285 & $7^{\text {th }}$ \\
7. & Lack of improved propagating materials & 273 & $8^{\text {th }}$ \\
8. & Lack of suitable selling center & 270 & $9^{\text {th }}$ \\
9. & Lack of transportation & 261 & $10^{\text {th }}$ \\
10. & Insufficient credit support & &
\end{tabular}

\section{CONCLUSION AND RECOMMENDATIONS}

An overwhelming majority (90.4\%) of the farmers had medium to high impact of flower cultivation on their livelihood. As it had a significant impact, attitudes towards flower cultivation increase the outlook of the farmers which lead them to practice flower cultivation with a view to enhancing the impact on their livelihood. High family income from flower cultivation encourages the farmers to practice flower cultivation since $78.3 \%$ flower cultivators had medium annual income from that practices. High literacy and educational level among the farmers influenced higher flower cultivation practices since level of education of the farmers proved as an important contributing factor. As it is a contributing factor high annual family income encourages the farmers to practice flower cultivation, rightly showed $71.3 \%$ flower cultivators had medium annual family income. Through flower cultivation knowledge an individual farmer became aware of the information on the various aspects of selected flower production practices. Consequently, they became motivated to practice flower cultivation. Study also showed that flower cultivation knowledge had a significant contribution to the impact of farmers' livelihood. The above facts lead to the conclusion that necessary arrangements should be made to increase the knowledge of farmers which would ultimately increase the flower cultivation with a view to enhancing the impact on farmers' livelihood.

Effective steps should be taken by the Department of Agricultural Extension (DAE) and Non- Government Organizations (NGOs) for strengthening the farmers' qualities in favour of flower cultivation to a higher degree for their livelihood improvement. It can be done by improving the attitude towards cultivation of flower, enhancing educational level of flower farmers, imparting sound knowledge about flower cultivation etc. Extension worker and other concerned authorities should provide supports to fulfil the above mentioned recommendations as well as motivating farmers to enhance their annual income from flower cultivation and also their annual family income.

\section{REFERENCES}

AGRISLIDE, (2017). Floriculture Production Practices in Bangladesh. A web portal on Agricultural Information. Retrieved from: http://www.agrislide.com/floricultureproduction-practices-in-bangladesh/

AVNIMELECH, Y. (1998). Minimal Discharge from Intensive Fishponds. World Aquaculture, 29: 32-37. Retrieved from: https://www.researchgate.net/publication/284392504_Mi nimal discharge from intensive fish ponds

BAGADE, A.D., TALATHI, J. M., NAIK, V. G. \& KAMBLE, S. H. (2008). Production and marketing of cut flower. Agriculture Update, 3(1/2): 131-136. Retrieved from:

https://www.cabdirect.org/cabdirect/abstract/2008326683 $\underline{5}$

BBS. (2011). The Yearbook of Agricultural Statistical of Bangladesh. Bangladesh Bureau of Statistics, Ministry of Planning, Government of the People's Republic of Bangladesh, Dhaka. Retrieved from: http://fpmu.gov.bd/agridrupal/content/yearbookagricultural-statistics-bangladesh-2011

BBS. (2014). Statistical Yearbook of Bangladesh, Bangladesh Bureau of Statistics, Statistics Division, Ministry of Planning, Government of People's Republic of Bangladesh, Dhaka. Retrieved from: https://www.esteri.it/mae/pubblicazioni/annuariostatistic o/statistical_yearbook_2014\%20web.pdf

BBS. (2015). Statistical Yearbook of Bangladesh, Bangladesh Bureau of Statistics, Statistics Division, Ministry of Planning, Government of People's Republic of Bangladesh, Dhaka. Retrieved from: http://203.112.218.65:8008/WebTestApplication/userfile s/Image/SubjectMatterDataIndex/YearBook15.pdf

BBS. (2016). Statistical Yearbook of Bangladesh, Bangladesh Bureau of Statistics, Statistics Division, Ministry of Planning, Government of People's Republic of Bangladesh, Dhaka. Retrieved from: http://bbs.portal.gov.bd/sites/default/files/files/bbs.portal. gov.bd/page/1b1eb817_9325_4354_a756 3d18412203e2 /Yearbook-2016-Final-19-06-2017.pdf

BOGDAN, R.C. \& BIKLEN, S. K. (2006). Qualitative Research for Education: An Introduction to Theory and Methods (5 $5^{\text {th }}$ ed.). Boston: Allyn \& Bacon.

BRYMAN, A. (2001). Social Research Methods. Oxford: Oxford University Press.

CHAMBERS, R. \& CONWAY, G. R. (1991). Sustainable Rural Livelihoods: Practical Concepts for the 21st Century. In IDS Discussion Paper 296.Institute of Development Studies (IDS), Brighton, GB.

DAE. (1999). Agriculture Extension Manual. Department of Agricultural Extension, Ministry of Agriculture, Government of the People's Republic of Bangladesh.

DONOHUE, C. R. (2003). Socio-Economic Impact: A Study of the Floriculture Industry in UGANDA. UGANDA'S Investment in Developing Export Agriculture (IDEA) Project.

ELLIS, F. (2000). Rural Livelihoods and Diversity in Developing Countries. Oxford: Oxford University Press. 
GAJANANA, S.M., T.M. \& DAKSHINAMOORTHY, V. (2005). Economic feasibility and profitability of carnation cultivation. J. of Ornamental Hort. (New Series) 8(4): 254-259.

GARBARINO, S. \& HOLLAND, J. (2009). Quantitative and qualitative methods in impact evaluation and measuring results: Issues paper. Governance and Social Development Resource Centre.

GHULE, T. \& MENON, S. (2013). Scope and Future of Floriculture Industry in India. Global J. for Res. Analysis, 2(2): 28-29.

HAQUE, M. A., MIAH, M., HOSSAIN, M. \& ALAM, M. (2012). Economics of Marigold Cultivation in Some Selected Areas of Bangladesh. Bangladesh J. Agril. Res., 37(4): 711-720. DOI: http://dx.doi.org/10.3329/bjar.v37i4.14395

MOU, N. H. (2012). Profitability of flower production and marketing system of Bangladesh. Bangladesh J. Agril. Res., $\quad 37(1)$ : 77-95. DOI: http://dx.doi.org/10.3329/bjar.v37i1.11179

HEMERT, N.V. (2005). E-business and the Dutch Flower Industry: A Survey for Strategic Opportunities. Presentation, International Agribusiness Management Association (IAMA).

IPCC. (1995). The Science of Climate Change. Summary of Policy Maker, Working Group 1. IPCC Second Assessment Synthesis.

JAHAN, H. (2009). Production, post-harvest handling and marketing of cut-flowers in Bangladesh: An agribusiness study. SAARC J. of Agric., 7(2):1-14.

MARTSYNOVSKA. (2005). The flower Business in EU. Retrieved from: www.globtdinfo.au2004
MAZUMDER, M.S.U. \& LU, W. (2015). What impact does microfinance have on rural livelihood? A comparison of governmental and non-governmental programs in Bangladesh. World Dev., 68: 336-354.

MINGERS, J. (2001). Combining IS Research Methods: Towards a Pluralist Methodology. Info. Sys. Res., 12(3): 240-259. Retrieved from: http://gkmc.utah.edu/7910F/papers/ISR\%20combining\% 20IS\%20research\%20methods.pdf

MoYS. (2012). The Population Category in Bangladesh. Ministry of Youth and Sports, Government of the People's Republic of Bangladesh.

SAYLA, K. (2010). An economic analysis of commercial floriculture in some selected areas of Bangladesh, M.Sc. (Ag. Econ.) Thesis, Bangladesh Agricultural University, Mymensingh.

SCOONES, I. (1998). Sustainable Rural Livelihoods: A Framework for Analysis IDS. Working Paper 72, Brighton, UK: Institute for Development Studies.

SERAJ, S. (2007). Potentiality of flower business in Bangladesh. Retrieved from: www.thedailystar.net

SULTANA, N. (2003). Floriculture Exports from Bangladesh. A paper presented in International Floriculture Conference on 6th November, BRAC, Farmgate, Dhaka. 